\title{
Noise due to Plunging Film-Flow
}

\author{
Atsushi Sasaki, Osamu Mochizuki, Masaru Kiya and Hitoshi Ishikawa
}

\begin{abstract}
Sound due to bubbles entrained by a vertical thin water-jet plunging into water was investigated. The sound source was discussed in relation to the size and spatial distribution of bubbles obtained by flow visualization. There were two particular frequencies corresponding to the distribution of bubbles in the transition state of the plunging jet ; one is originated in the bubbles in a cluster, the other is related to the cluster. Deformation of bubbles and non-uniformity in size and distribution of bubbles are important for modification of predication of sound generated by the bubble cluster.
\end{abstract}

Keywords: Sound, Bubble, Plunging jet, Entrainment, Cluster

\section{1.はじめに}

水膜流が水面に突入する際, 気泡が取り込まれるこ とによって発生する音を調べた。発生音源を評価する ため, 気泡直径と気泡分布を計測した。この結果, 発 生音の周波数を予測するためには, 気泡群を特徵づけ る代表寸法の規定が重要であることを指摘した。

\section{2. 实験装置}

高さ $\mathrm{H}=1.5 \mathrm{~mm}$, 幅 $50 \mathrm{~mm}$ のノズルから垂直壁面に 沿って噴出する水膜流を静止水面に突入させた. 水面 への突入速度 $V$ を $0.44-4.22 \mathrm{~m} / \mathrm{s}$ に変化させることで 水膜流を層流から乱流へ変化させた．レイノルズ数は $R_{e}=550-5700$ (= $\mathrm{H} V / v, v$ : 水の動粘性係数)であった.

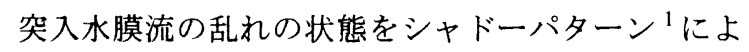
る可視化映像から判定した. 本実験において水膜流が 遷移状態である流速は $V=0.66-2.66 \mathrm{~m} / \mathrm{s}$ であった。

気泡群から発生する音を水中マイクロフォン $(\mathrm{B} \& \mathrm{~K}$ 8103)を用いて計測した. 発生音の計測は水面下 $10 \mathrm{~mm}$, ガラス壁面より $10 \mathrm{~mm}$ の位置で行った. 周波数解析で は200 回のスペクトルデータを平均した.

\section{3. 实験結果}

\section{1 発生音と気泡分布}

気泡群から発生する音の SPL を Fig.1 に示す. SPL

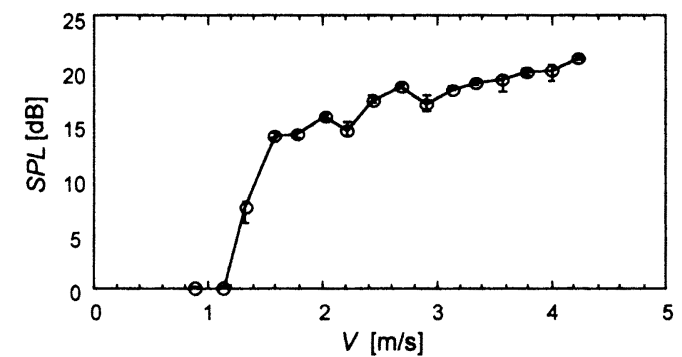

Fig.1 Sound pressure level for different $V$.
の值は暗騒音レベルを基準とした。本実験では $V \geqq$ $1.33 \mathrm{~m} / \mathrm{s}$ の場合に音が発生した.このとき水膜流は遷移 初期の状態である.Vの増加とともに SPL も増加する ことがわかる．音が発生するときには必ず気泡が取り 込まれている. 水膜流の乱れの出現と気泡の取り込み は密接に関わっていることが著者らによって明らかに されている 2 .

水膜流が遷移状態と乱流状態のときにおける発生音 の周波数スペクトルを Fig.2 に示す. 水膜流が遷移状 態 $(V=2.66 \mathrm{~m} / \mathrm{s})$ のとき, 発生音には 2 つのピーク周波数 $f_{1}=4600 \mathrm{~Hz}, f_{2}=6900 \mathrm{~Hz}$ が現れる. 一方, 乱流状態 $(V=3.77 \mathrm{~m} / \mathrm{s})$ では, $f_{l}=4500 \mathrm{~Hz}$ にのみピークが現れる. 周波数 $f_{l}$ は両者で共通して現れるため, 水膜流の乱れ が関わっているものと考えられる.

この音の発生源を考えるために, 取り込まれた気泡の 分布を調べた．その結果をFig.3に示す．Fig.3(a)は水膜 流が遷移状態にあるときのものであり, 気泡が密集した 部分（クラスタ）と㻋の部分とが存在している.Fig.3(b) に示した乱流状態では，明確なクラスタは存在せず，
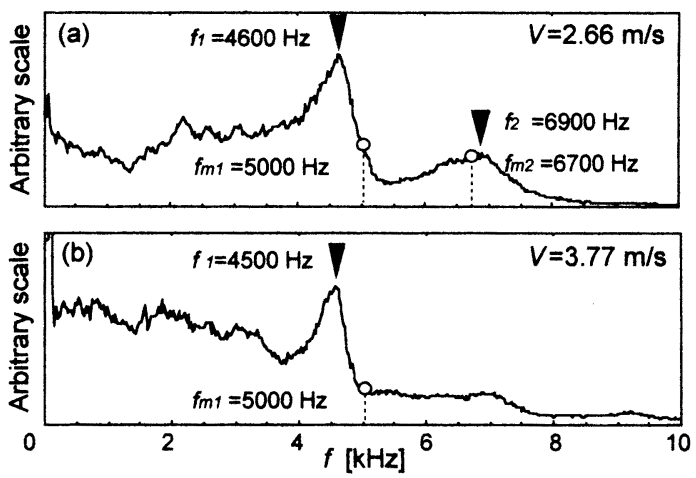

Fig. 2 Spectrum of sound generated by bubbles in clusters. The state of plunging water-jet is in (a) transition state, (b) turbulent state. 
佐々木篤史，望月 修，木谷 勝，石川 仁

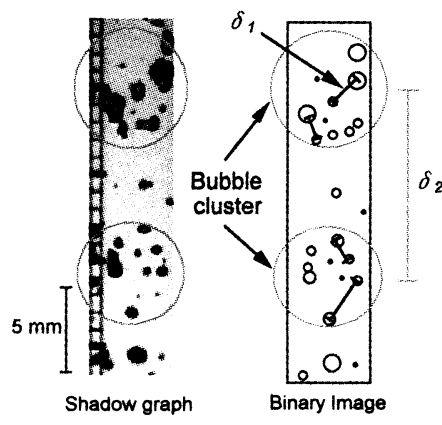

(a) $V=2.66 \mathrm{~m} / \mathrm{s}$
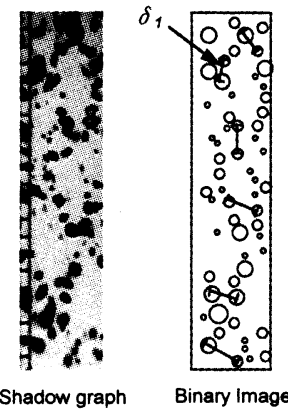

(b) $V=3.77 \mathrm{~m} / \mathrm{s}$
Fig.3 Characteristic sizes and distances of entrained bubbles for different states of the plunging water-jet. (a) transition state, (b) turbulent state.
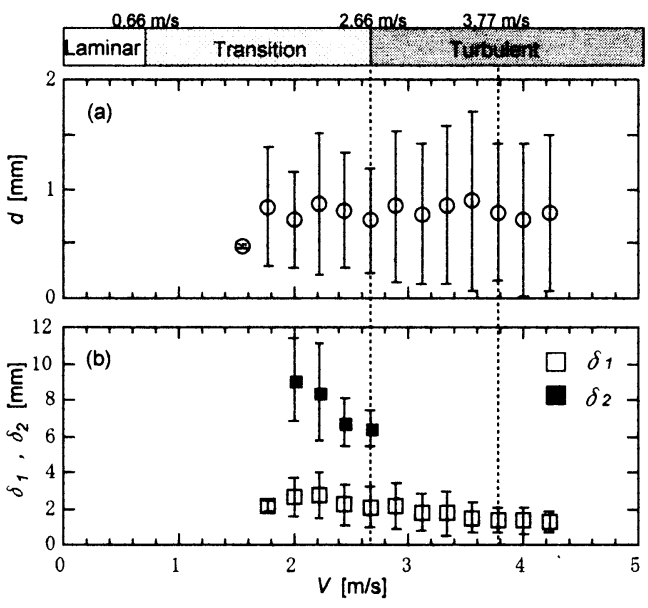

Fig.4 Changes in size and spatial distance of entrained bubbles for different $V$. (a) diameter of bubble, (b) characteristic distance between bubbles.

気泡は不規則に分布している。

これらのことを定量的に評価するため, 可視化写真 から気泡直径 $d$ と気泡間距離 $\delta$ を計測した。 突入速度 に対する気泡直径の変化を Fig.4(a)に示す．気泡の平 均直径は $V$ に対してほぼ一定であり, $0.8 \mathrm{~mm}$ 程度であ る.したがって，遷移状態と乱流状態で共通して存在 する小規模乱れのスケールが気泡直径の決定に関係し ていると考えられる.

これに対して気泡間距離の $V$ に対する変化を Fig.4(b)に示す．ここで注目すべきことは，遷移状態 $(V=2.66 \mathrm{~m} / \mathrm{s})$ のときには 2 つの特徵的な長さ $\delta_{1}, \delta_{2}$ (Fig.3 参照)が現れ，乱流状態 $(V=3.77 \mathrm{~m} / \mathrm{s})$ では $\delta_{1}$ のみ 現れることである。したがって，これらの代表スケー ルが発生音の周波数決定に関倸しているものと考えら れる。

同一直径をもつ気泡が等間隔に位置する気泡群の振 動解析 ${ }^{3}$ によると, 気泡群の固有振動数 $f_{m}$ は気泡間距 離が短くなると，その直径をもつ単独気泡の振動周波 数より低くなることが示されている.この解析に従い， Fig.4 で示した $d=0.8 \mathrm{~mm}, \delta_{I}=1.7 \mathrm{~mm}(V=2.66 \mathrm{~m} / \mathrm{s})$ を与 えることでバブルクラスタの固有振動数を求めた. 計 算によって得られる固有振動数は $f_{m l}=5000 \mathrm{~Hz}$ であり， (a)

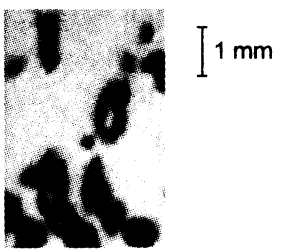

(b)

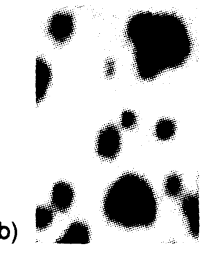

Fig.5 The shape of bubbles at different positions in the case of $V=3.77 \mathrm{~m} / \mathrm{s}$. Positions are (a) $6 \sim 12 \mathrm{~mm}$, (b) 20 26mm below water surface.

これを Fig.2 に○で示した。この值は遷移状態, 乱流 状態で現れた $f_{l}$ と比較すると有意な差がある。この原 因については 3.2 節で考察する.

さらに遷移状態において， $\delta_{1}$ のかわりにクラスタ 間の距離である $\delta_{2}(=6.6 \mathrm{~mm})$ を与えると $f_{m 2}=6700 \mathrm{~Hz}$ 得る.この值は Fig.2(a)に示した実測值 $f_{2}=6900 \mathrm{~Hz}$ に 相当するものであると考えられ，クラスタ間の平均距 離に対応する周波数であるといえる，すなわち，気泡 間距離がある程度以上離れると解析結果は実験值とよ い一致を示すことがわかる。

\section{2 解析結果と实測值との相遣}

$f_{l}$ と $f_{m l}$ の差の原因を考えるために, 実際の気泡の形状 および分布の様子を調べた。結果を水面からの距離にわ けてFig.5に示す. どちらの位置でも気泡の大きさは一様 でなく，また気泡間距離も一定ではないことがわかる。 さらに，下流の気泡がほぼ球形とみなせるのに対し，連 行直後の気泡は流れ方向に伸ばされていることがわか る.これは突入水膜流のせん断層による伸張のためであ ると考えられる。したがって振動解析モデルとこれらの 違いを考慮する必要がある．たとえば，振動モードとし て膨張・収縮による0次のものだけではなく伸張に関す る2次モードのものも考慮すること，気泡の直径分布お よび気泡間距離分布を考慮することなどが必要である.

\section{4. おわりに}

連行気泡と発生音の関係を調べ, 次の結果を得た。 水膜流が遷移状態で水面に突入するとき, 発生音に

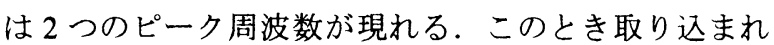
万気泡閒距離には水膜流の乱流構造に関わる $2 つ$ つ特 徵的なスケールがあり，それぞれがピーク周波数に対 応している．気泡群からの発生音の周波数を予測する には, 気泡群における直径および気泡間距離の不均一 性および気泡形状を考慮することが重要である.

\section{参考文献}

1. Azuma, T. and Hoshino, T., The Radial Flow of a Thin Liquid Film (1st Report, Laminar-Turbulent Transition), Bulletin of JSME, Vol. 27 No. 234 (1984), pp. 2739-2746.

2. 佐々木篤史, 望月修, 木谷勝, 突入水膜流によって発生 する音, 日本流体力学会, ながれ, 18(1999), pp377-386.

3. Takahira, H., Akamatsu, T. and Fujikawa, S., Dynamics of a Cluster of Bubbles in a Liquid (Theoretical Analysis), JSME International Journal, Series B Vol. 37 No. 2 (1994), pp. 297-305. 